\title{
EDXRF Spectroscopic Elemental Analysis for Efficacy of Kibabii University Sewage Treatment System
}

\author{
Yonah Situma, Jared Oloo Odhiambo, John Wanjala Makokha \\ Department of Science Technology and Engineering, Kibabii University, Bungoma, Bungoma County, Kenya \\ Email: yonasituma@yahoo.com
}

How to cite this paper: Situma, Y., Odhiambo, J.O. and Makokha, J.W. (2018) EDXRF Spectroscopic Elemental Analysis for Efficacy of Kibabii University Sewage Treatment System. Open Access Library Journal, 5: e4992.

https://doi.org/10.4236/oalib.1104992

Received: October 18, 2018

Accepted: November 16, 2018

Published: November 19, 2018

Copyright $\odot 2018$ by authors and Open Access Library Inc.

This work is licensed under the Creative Commons Attribution International License (CC BY 4.0).

http://creativecommons.org/licenses/by/4.0/

\begin{abstract}
Elemental analysis of sewage effluents in Kibabii sewage treatment system was achieved via Energy-Dispersive X-Ray Fluorescence (EDXRF) spectroscopy with the aim of assessing the efficacy of the treatment system. Concentrations of lead $(\mathrm{Pb})$, mercury $(\mathrm{Hg})$, cadmium $(\mathrm{Cd})$ and arsenic (As) were measured based on clay soil "standards" in concentration range for $\mathrm{Pb}, \mathrm{Hg}$ and As as $12.7 \mathrm{ppm}, 14.3 \mathrm{ppm}$ and $8.83 \mathrm{ppm}$ respectively for certification. Among other probable reference materials, clay soil "standards" were used for certification in this work because of similarity in matrix composition with the sediments. The concentration for $\mathrm{Hg}, \mathrm{Pb}$, and $\mathrm{As}$ in the sewage sediments were $10.65 \pm 2.28 \mathrm{ppm}, 8.86 \pm 2.92 \mathrm{ppm}$ and $3.41 \pm 2.18 \mathrm{ppm}$ respectively in lagoon A. In lagoon B the levels were $3.82 \pm 0.56 \mathrm{ppm}, 6.35 \pm 1.50 \mathrm{ppm}$ and $1.67 \pm 0.53 \mathrm{ppm}$ respectively. Lagoon $\mathrm{C}$ showed a reduction in the levels with $3.74 \pm 1.39 \mathrm{ppm}$ for $\mathrm{Hg}$ and $2.30 \pm 0.27 \mathrm{ppm}$ for $\mathrm{Pb}$. As was not detected in lagoon $\mathrm{C}$, on the other hand, $\mathrm{Cd}$ was not detected in all the lagoons. The efficacies in the treatment varied from $30.34 \%-51.78 \%, 37.63 \%-65.41 \%$ and $76.63 \%-84.81 \%$ for lagoon A, B and C respectively. The study was successful in quantifying the heavy elements in the lagoons from which the efficacy in the treatment process was determined. The study provided awareness on the elemental concentration levels in the Kibabii University sewage treatment system, hence creating awareness on what is released into River Kibabii. With this information, the surrounding community and the University can partner in order to mitigate the effects of heavy metals in the effluents in future due to the growth of the University day by day.
\end{abstract}

\section{Subject Areas}

Mechanical Engineering 


\section{Keywords}

Sewage Effluents, River Kibabii, Kenya, Heavy Metals

\section{Introduction}

Heavy metals have adverse effects both to human beings and animals which include: osteoporosis; liver diseases; kidney diseases; harmful on lungs and immune system [1]. A number of researches have been done on sewage effluents which have revealed an increasing concentration in water sources [2]. Sources of exposure of toxicity of heavy elements among others include: fish; dental fillings; fluorescent bulbs which use electricity to excite mercury vapor and thermometers that uses mercury as their thermometric liquid [3]. Metal bio-accumulation is a major route through which increased levels of pollutants are transferred across food chain web creating health problems whenever man is involved in the food chain [3]. There is a need to monitor this rate at which the concentration of heavy elements is increasing in the water sources so as to check the hazardous effects caused by them both to human beings and animals. Untreated or poorly treated sewage effluents contain high levels of biochemical oxygen demand (BOD), phosphorous and nitrogen that can be poisonous if released to waterways, harming aquatic animals and to large extent human beings [4]. Waste water treatments are important means to control transmission of pathogens to humans as pathogen concentrations vary with time hence monitoring need to be done to monitor their concentrations [5].

Water quality studies conducted in South Africa revealed poor operation and maintenance of wastewater and sewage treatment infrastructure as the cause of pollution of water sources; hence there was a need of finding ways to sustain the quality of water sources [6]. It was noted that too high inflow load in to Keiskammhoek treatment plant resulted in a poor level of wastewater and sewage purification hence polluting Keiskamma River causing serious health hazards to water users; as a result, there was a need to quickly and adequately address maintenance of sewage treatment plants to counter the hazards on the users [6]. A report from assessment of pollution levels of Msimbazi River in Tanzania from local slaughterhouse by a non-governmental organization pointed out an increase in pollution levels due to release into the River and recommended rehabilitation of the River in order to address this pollution [7]. National water and Sewerage Corporation in Uganda employs conventional sewage treatment works only at Bugolobi and Masaka treatment works while the rest of sewage goes into natural wetlands without treatment posing great risk of contracting diseases such as cholera spread due to poor sanitation [8].

A study done in Kenya on Sambul River showed that proper treatment of sewage to remove organic matter, nutrients and suspended solids is necessary in order for pollution of water bodies by effluents from septic tank to decrease [9]. 
Sewage effluent discharges must meet acceptable environmental standards to ensure environmental protection as indiscriminate sewage release into water bodies lower water quality compromising the health of the users in the long run [9]. The study indicated total phosphorous $(2.02 \mathrm{mg} / \mathrm{l})$, total suspended solids $(4.69 \mathrm{mg} / \mathrm{l})$ and biochemical oxygen demand $(17.99 \mathrm{ml} / \mathrm{l})$ which was within the permissible levels by National Environment and Management Authority (NEMA), but there was need to enhance more treatment practices to contain these levels [9]. There was an outcry for immediate action to be taken to save River Riana from raw sewage released from Suneka treatment plant due to overflow which tampered with treatment process, as its waters are used by local farmers for irrigation and domestic use hence if not addressed immediately, it could expose them to great danger [10]. A research on sewage effluents in Kisumu by NEMA and World Bank showed that Kisat River, the recipient of sewage effluents discharged into Lake Victoria poses a health risk to the immediate residents and water users [11]. There was need therefore to focus on the analysis of heavy elements in sewage effluents such as mercury $(\mathrm{Hg})$, arsenic $(\mathrm{As})$, lead $(\mathrm{Pb})$ and cadmium (Cd) concentrations in the Kibabii University sewage treatment system so as to establish their concentrations hence the risk to the target population can be predicted and thus, possible measures can be proposed to manage the effects of these heavy elements. The findings can then be utilized to determine the efficiency of the sewage treatment system under consideration.

Conventional methods of sample analysis such as atomic absorption spectroscopy (AAS) and inductively coupled plasma (ICP) techniques are laborious, expensive, involve wet digestion and prone to inaccuracy due to the possibility of contamination during digestion process due to reagents used, therefore, spectroscopic techniques such as EDXRF which is non-destructive, rapid, affordable , entails easy sample preparation and enables data measurements with low background and high peak-to-background ratio can be applied in sample analyses [12] [13].

Energy Dispersive X-Ray Fluorescence (EDXRF) analyses both liquid and solid samples hence can be used as a technique for multi-elemental analysis in a large variety of samples [14].

\section{Materials and Methods}

\subsection{Study Area}

The site of study is within Kibabii University in Bungoma County along Bungoma-Chwele road, $7 \mathrm{~km}$ from Bungoma town. The University's sewage treatment system is located in the southern end of the University.

\subsection{Sample Collection and Preparation}

Samples from Kibabii University sewage treatment system were collected using droppers for liquid samples and spatula for sediments (after being brought out of the lagoon using a wire mesh-reinforced rake) then stored in air-tight bottles. 
The treatment system is stratified into lagoons. Lagoon $\mathrm{A}$ is the largest lagoon ( $32 \mathrm{~m}$ by $11 \mathrm{~m}$ ) while $\mathrm{B}, \mathrm{C}$ and $\mathrm{D}$ are of the same size $(23 \mathrm{~m}$ by $11 \mathrm{~m}$ ). Liquid and sediment samples were collected as follows: Lagoon A (three liquid and sediment samples from each corner of the lagoon and across the lagoon at the middle whereas; Lagoons B, C and D, three liquid and sediment samples from each corner of the lagoon were collected.

In all the three lagoons, there was a distance of $2 \mathrm{~m}$ apart from one sampling point to the next in order to get samples representing the whole sampling area (Figure 1).

After samples were collected, Labeling was done indicating the lagoon from which the sample is collected, the point of collection and the order of sampling process. For instance, AS1 imply sampling site one in Lagoon A; BS3 imply sample site three in Lagoon B; whereas DS2 imply sampling site two in Lagoon D. Within sampling site one in Lagoon A (AS1), there are three samples collected a distance of $2 \mathrm{~m}$ from each other in order of AS11, AS12 and AS13 (Figure 1). This happens in all sample sites.

After collection, sediment samples were dried in the oven over aluminum foil at a temperature of $70^{\circ} \mathrm{C}$ until they were completely dry. Once dry, each sample was crushed in a separate mortar and pestle (to avoid cross contamination) to fine powder. The powder for each sample was sieved (sieve size $<60 \mu \mathrm{mm}$ ) to remove large particles. $2 \mathrm{~g}$ of powder of each sample measured (using a top pan balance) for uniform pellets. Each powder of mass $2 \mathrm{~g}$ was poured into a dice and subjected to a pressure of 8 millibars inside the hydraulic press until fully compacted. Pellets of diameter $25 \mathrm{~mm}$ were made corresponding to the inner diameter of the dice. Once the pellets were made, they were put in metal cups for analysis by EDXRF spectrometer.

\section{Results and Discussions}

Tables 1-3 show average concentration of heavy metals under study across the lagoons.

\subsection{Hg Concentration Level across the Lagoons}

Mercury concentration level at the entrance (AS1) averaged $13.62 \pm 1.38 \mathrm{ppm}$ (Table 1).

This high concentration was also observed in the study of the removal of $\mathrm{Hg}$ from chloralkali Electrolysis wastewater by a mercury-resistant pseudomonas pudida strain [15]. The researchers recorded a range of $1.6 \mathrm{mg} / \mathrm{l}$ to $7.6 \mathrm{mg} / \mathrm{l}$ with $7.6 \mathrm{mg} / \mathrm{l}(1 \mathrm{ppm}=1 \mathrm{mg} / \mathrm{l}) \mathrm{Hg}$ concentration at the start of the removal process [15]. The onset of the removal process of $\mathrm{Hg}$ from chloralkali Electrolysis wastewater was slightly lower than the entrance value of $\mathrm{Hg}$ at the entrance recorded in this work. The Hg concentration level varied from non-detection to 10 $\mathrm{mg} / \mathrm{kg}$ at the outlet and inlet respectively [16]. The Hg entrance concentration level in this work is more closer to the one noted in the study than the one recorded 


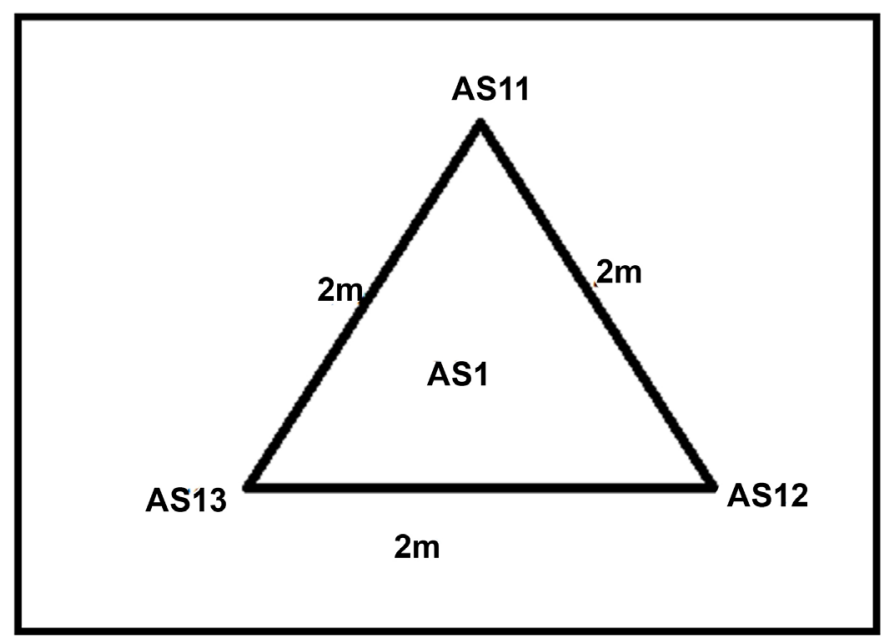

Figure 1. Sampling procedure used in the collection of samples e.g. AS1.

Table 1. Average $\mathrm{Pb}, \mathrm{Hg}, \mathrm{Cd}$ and As concentration in lagoon A.

\begin{tabular}{ccccc}
\hline Sample & \multicolumn{4}{c}{ Concentration in ppm } \\
\hline & $\mathrm{Hg}$ & $\mathrm{Pb}$ & $\mathrm{As}$ & $\mathrm{Cd}$ \\
\hline $\mathrm{AS} 1$ & $13.62 \pm 1.38$ & $13.83 \pm 0.46$ & $7.75 \pm 0.25$ & $\mathrm{ND}$ \\
$\mathrm{AS} 2$ & $8.52 \pm 0.06$ & $10.46 \pm 3.38$ & $2.14 \pm 0.64$ & $\mathrm{ND}$ \\
$\mathrm{AS3}$ & $\mathrm{ND}$ & $9.57 \pm 1.37$ & $2.38 \pm 0.89$ & $\mathrm{ND}$ \\
AS4 & 7.50 & $12.23 \pm 0.84$ & $2.63 \pm 0.24$ & $\mathrm{ND}$ \\
AS5 & $5.79 \pm 1.15$ & $7.16 \pm 1.95$ & $2.15 \pm 0.29$ & $\mathrm{ND}$ \\
\hline
\end{tabular}

at the beginning of $\mathrm{Hg}$ removal process in [15], however, the studies converge at the same point of high concentration at entrance compared to low concentration at exit. $\mathrm{Hg}$ concentration levels at the second, fourth and fifth (outlet) sampling points in lagoon $\mathrm{A}$, averaged $8.52 \pm 0.06 \mathrm{ppm}, 7.50 \mathrm{ppm}$ and $5.79 \pm 1.15 \mathrm{ppm}$ respectively with non-detection at third sampling point (AS3) (Table 1). These $\mathrm{Hg}$ concentrations levels depicted a downward trend comparing the inlet concentration in lagoon A (13.62 $\pm 1.38 \mathrm{ppm})$ and outlet concentration (5.79 \pm 1.15 ppm).

In lagoon $\mathrm{B}, \mathrm{Hg}$ concentration level averaged $4.53 \pm 0.21 \mathrm{ppm}$ at the entrance and $2.96 \pm 0.50 \mathrm{ppm}$ at the exit with an average of $3.87 \pm 0.85 \mathrm{ppm}$ and $3.93 \pm$ $0.36 \mathrm{ppm}$ at BS2 and BS3 respectively (Table 2). This reduction on the concentration level at the inlet of lagoon B compared to outlet concentration in the same lagoon can be attributed to the efficacy in the treatment process of the sludge in the lagoon. $\mathrm{Hg}$ concentration in lagoon $\mathrm{C}$ ranged from $2.83 \pm 0.36 \mathrm{ppm}$ to $2.24 \mathrm{ppm}$ at the inlet and outlet respectively (Table 3 ). There was a slight reduction in the $\mathrm{Hg}$ concentration from the inlet to the outlet of lagoon $\mathrm{C}$ which can be attributed to the refinement of the treatment process in this lagoon. Lagoon $\mathrm{D}$ registered no detection of $\mathrm{Hg}$ both in liquid samples and sediments which was pointed towards the treatment process in lagoon $\mathrm{C}$ and $\mathrm{D}$. It was realized 
Table 2. Average $\mathrm{Hg}, \mathrm{Pb}$, As and Cd concentration levels in sediments from lagoon $\mathrm{B}$.

\begin{tabular}{ccccc}
\hline Sample & \multicolumn{4}{c}{ Concentration in ppm } \\
\hline & $\mathrm{Hg}$ & $\mathrm{Pb}$ & $\mathrm{As}$ & $\mathrm{Cd}$ \\
\hline $\mathrm{BS} 1$ & $4.53 \pm 0.21$ & $5.80 \pm 2.19$ & $2.14 \pm 0.98$ & $\mathrm{ND}$ \\
$\mathrm{BS} 2$ & $3.87 \pm 0.85$ & $5.48 \pm 2.51$ & $1.95 \pm 0.67$ & $\mathrm{ND}$ \\
$\mathrm{BS3}$ & $3.93 \pm 0.36$ & $8.93 \pm 2.92$ & 1.82 & $\mathrm{ND}$ \\
$\mathrm{BS} 4$ & $2.96 \pm 0.50$ & $5.21 \pm 1.54$ & $0.78 \pm 0.42$ & $\mathrm{ND}$ \\
\hline
\end{tabular}

Table 3. Average $\mathrm{Hg}, \mathrm{Pb}$, As and Cd concentration levels in sediments from lagoon $\mathrm{C}$.

\begin{tabular}{ccccc}
\hline Sample & \multicolumn{4}{c}{ Concentration in ppm } \\
\hline & $\mathrm{Hg}$ & $\mathrm{Pb}$ & $\mathrm{As}$ & $\mathrm{Cd}$ \\
\hline $\mathrm{CS} 1$ & $2.83 \pm 0.36$ & $2.40 \pm 0.65$ & $\mathrm{ND}$ & $\mathrm{ND}$ \\
$\mathrm{CS} 2$ & 4.02 & $2.44 \pm 0.1$ & $\mathrm{ND}$ & $\mathrm{ND}$ \\
$\mathrm{CS} 3$ & 5.88 & $2.53 \pm 0.49$ & $\mathrm{ND}$ & $\mathrm{ND}$ \\
$\mathrm{CS} 4$ & 2.24 & $1.84 \pm 0.36$ & $\mathrm{ND}$ & $\mathrm{ND}$ \\
\hline
\end{tabular}

that the concentration levels of $\mathrm{Hg}$ greatly reduced from the inlet concentration of $13.62 \pm 1.38 \mathrm{ppm}$ in lagoon A and zero concentration in Lagoon D, an indicator of quality treatment by the treatment system. The low concentration of $\mathrm{Hg}$ at the outlet was also noted in the investigation of concentration levels of toxic elements in sewage sludge [17]. The researchers observed $\mathrm{Hg}$ concentration level of less than $0.2 \mathrm{mg} / \mathrm{kg}(1 \mathrm{ppm}=1 \mathrm{mg} / \mathrm{kg}$ ) which was relatively higher than the $\mathrm{Hg}$ outlet concentration in this work. $0.73 \pm 0.20 \mathrm{mg} / \mathrm{l}$ and $4.8 \pm 1.45 \mathrm{mg} / \mathrm{l} \mathrm{of} \mathrm{Hg}$ was realized during the analysis of $\mathrm{Hg}$ variation in effluents from two municipal wastewater treatment plants [18]. These two values are lower that the $\mathrm{Hg}$ inlet concentration in this work but higher than the outlet concentration, an indicator that Kibabii sewage treatment system is better placed in $\mathrm{Hg}$ treatment so as safe limits are observed while the effluent is released in River Kibabii.

\section{2. $\mathrm{Pb}$ Concentration Level across the Lagoons}

Lead $(\mathrm{Pb})$ inlet concentration into the treatment system in lagoon A averaged $13.83 \pm 0.46 \mathrm{ppm}$ (Table 1 ) which was higher than the other sampling points in Lagoon A. An investigation of $\mathrm{Pb}$ concentration from sewage effluents from tannery and textile industry recorded $\mathrm{Pb}$ range of $2.89 \mathrm{ppm}-3.03 \mathrm{ppm}$ in tannery effluents and $0.96 \mathrm{ppm}-3.89 \mathrm{ppm}$ for textile industry [19]. The researcher realized lower $\mathrm{Pb}$ value than the $\mathrm{Pb}$ inlet concentration in this work since they were partially treated before release, while for our case, $\mathrm{Pb}$ gains entry into the treatment system at this point hence the high concentration [19]. The high $\mathrm{Pb}$ concentration in the sewage effluents was also observed ranging from $100 \mathrm{mg} / \mathrm{kg}$ to $350 \mathrm{mg} / \mathrm{kg}(1 \mathrm{ppm}=1 \mathrm{mg} / \mathrm{kg})$ in Bangkok central wastewater sewage treatment plant [16]. The researcher's values were much higher than $\mathrm{Pb}$ concentra- 
tion levels in this study which can be explained in terms of the small capacity of Kibabii University Sewage treatment system serving a smaller population hence lesser $\mathrm{Pb}$ loadings. $\mathrm{Pb}$ recorded an average concentration of $10.46 \pm 3.38 \mathrm{ppm}$, $9.57 \pm 1.37 \mathrm{ppm}, 12.23 \pm 0.84 \mathrm{ppm}$ and $7.16 \pm 1.95 \mathrm{ppm}$ (Table 1) at second (AS2), third (AS3), fourth (AS4) and fifth (AS5) sampling points respectively in lagoon A. This variation also depicts a downward trend from the inlet $(13.83 \pm$ $0.46 \mathrm{ppm})$ to the outlet $(7.16 \pm 1.95 \mathrm{ppm})$ an indicator of the $\mathrm{Pb}$ treatment in this lagoon as the raw sewage from the septic tank gains entry in the treatment system. There was relatively slight variability of $\mathrm{Pb}$ concentration at the inlet of Lagoon B $(5.80 \pm 2.29 \mathrm{ppm})$ and outlet concentration $(5.21 \pm 1.54 \mathrm{ppm})$ which at the same time indicated some reduction in the $\mathrm{Pb}$ concentration (Table 2). By the time the slurry leaves the treatment system from Lagoon $\mathrm{D}$ to the River, $\mathrm{Pb}$ was not detected due to the efficient treatment process. A research done in Ondo state, Nigeria did not detect presence of $\mathrm{Pb}$ after treatment [20]. This was in agreement with the findings of this study which is majorly a pointer towards efficient treatment of $\mathrm{Pb}$ as the treated effluent enters the River. Study on milk recorded $\mathrm{Pb}$ concentration range of $0.4-0.8 \mathrm{ppm}$ in milk contents from cows grazing on grass grown in areas near the passage of industrial sewage effluents [21]. His values were slightly higher than the $\mathrm{Pb}$ concentrations at the outlet of the treatment system in this work which can be pointed towards the Pb loadings in the effluents from the textile industry under investigation [21]. An investigation on heavy metal contamination of soils and vegetables irrigated with municipal wastewater realized $0.88 \pm 0.18 \mathrm{ppm}$ which was higher than the maximum permissible levels by world health organization [22] [23]. It was noted that the levels in the sewage effluents themselves could be higher than the $\mathrm{Pb}$ concentration in the irrigated vegetables since not all the $\mathrm{Pb}$ concentration is absorbed by the vegetables [22].

\subsection{Arsenic (As) Concentration across the Lagoons}

Arsenic (As) at the entrance in lagoon A averaged $7.75 \pm 0.25 \mathrm{ppm}$ (Table 1). There was a decrease in the concentration level as the treatment goes on in Lagoon A with an average of $2.14 \pm 0.64 \mathrm{ppm}, 2.38 \pm 0.89 \mathrm{ppm}, 2.63 \pm 0.24 \mathrm{ppm}$ and $2.15 \pm 0.29 \mathrm{ppm}$ at second (AS2), third (AS3), fourth (AS4) and fifth (AS5) sampling points respectively (Table 1). A range of $10 \mathrm{ppm}$ to $100 \mathrm{ppm}$ of As was noted in the determination of heavy metal content and their variation in sewage effluents [16]. The entrance concentration in this work is slightly lower than the one noted in [16] due to difference in area under consideration [16]. Study on heavy metal elements in municipal sewage treatment plant recorded Arsenic range of $6.3 \mathrm{mg} / \mathrm{kg}$ to $9.2 \mathrm{mg} / \mathrm{kg}(1 \mathrm{ppm}=1 \mathrm{mg} / \mathrm{kg})$ concentration which was in agreement with As entry concentration in this work [17]. The research embraced a combined spectroscopic technique in his analysis which gave a concentration level which was still closer to the level in this work using EDXRF spectroscopy. A study on effluents pointed out As concentration range of $4.5 \mathrm{ppm}$ to $6.6 \mathrm{ppm}$ 
in untreated effluents from textile industry which was slightly lower than the entry concentration in this work $(7.75 \pm 0.25 \mathrm{ppm})$ [19]. The lower concentration was due to the fact that the study was conducted to the partially treated effluent unlike the case of our study where the slurry gains entrance in the lagoons for treatment to commence [19]. In lagoon B, As concentration was $2.14 \pm 0.98$ ppm, $1.95 \pm 0.67 \mathrm{ppm}, 1.82 \mathrm{ppm}$ and $0.78 \pm 0.42 \mathrm{ppm}$ in the first (BS1), second (BS2), third (BS3) and fourth (BS4) sampling points respectively (Table 2) from the inlet (BS1) to the outlet (BS4). There was a general downward trend as the slurry enters lagoon B all the way to the outlet attributed to the treatment process in the lagoon. Arsenic was not detected in lagoon C and D in both the liquid samples and sediments which shows that it was well treated in lagoon $\mathrm{B}$. With an entry concentration of $7.75 \pm 0.25$ ppm (Lagoon A) and zero concentration at the outlet of lagoon D clearly shows that treatment took place as the raw sewage enters the treatment system. Various studies of As concentrations in sewage effluents have revealed values of As slightly higher than the levels in this work but all support the reduction idea due to treatment process. $1.14 \mathrm{mg} / \mathrm{l}$ (1 $\mathrm{ppm}=1 \mathrm{mg} / \mathrm{l}$ ) of As concentration in sewage effluents was observed [24] which was slightly above the level realized at the exit in this work. Through the sudy of quantifying and investigation of heavy metal removal from the sewage effluents, better practices were proposed which improved sewage treatment and management [24]. As concentration of $0.55 \pm 0.08 \mathrm{mg} / \mathrm{kg}(1 \mathrm{ppm}=1 \mathrm{mg} / \mathrm{kg})$ in his study on industrial sewage contents in Ondo estate [20] which was in agreement with the one from [24] but slightly higher than the value in this work suggesting quality treatment by the system. On the other hand, a study on effluents from tannery industry realized $1.07 \mathrm{ppm}$ to $0.45 \mathrm{ppm}$ As [19] which was still closer to the one observed in [20] and [24] which supports the same idea that the As concentration level reduce when the sludge is subjected to treatment.

\subsection{Efficacy of the Treatment System}

An overall comparison of the variability from lagoon A to lagoon D clearly pointed out the reduction in the heavy metal concentration levels (Figure 2).

The downward trend of the heavy metals from the first lagoon to the last lagoon is due to the combined primary and secondary treatment processes in the lagoons. Evaluation of efficacy in $\mathrm{Hg}$ treatment gave $57.47 \%$, 34.66\% and $20.85 \%$ for lagoons A, B and C (Figure 3). The absence of $\mathrm{Hg}$ in lagoon D was an indicator of quality treatment of this heavy element in the lagoons. Efficacy in the treatment in lagoon $\mathrm{A}$ was higher compared to that of $\mathrm{B}$ and $\mathrm{C}$ since major treatment takes place in this lagoon due to large amounts of sewage coming in. There was a reduction in the efficacy in the treatment of $\mathrm{Hg}(34.66 \%-20.85 \%)$ from the second lagoon to the third lagoon. This suggests that lagoon $\mathrm{C}$ is basically a refinement lagoon which removes what was not removed as the slurry passes through these lagoons.

Efficacy in the treatment of $\mathrm{Pb}$ was $48.23 \%, 10.17 \%$ and $23.33 \%$ in lagoons $\mathrm{A}$, 


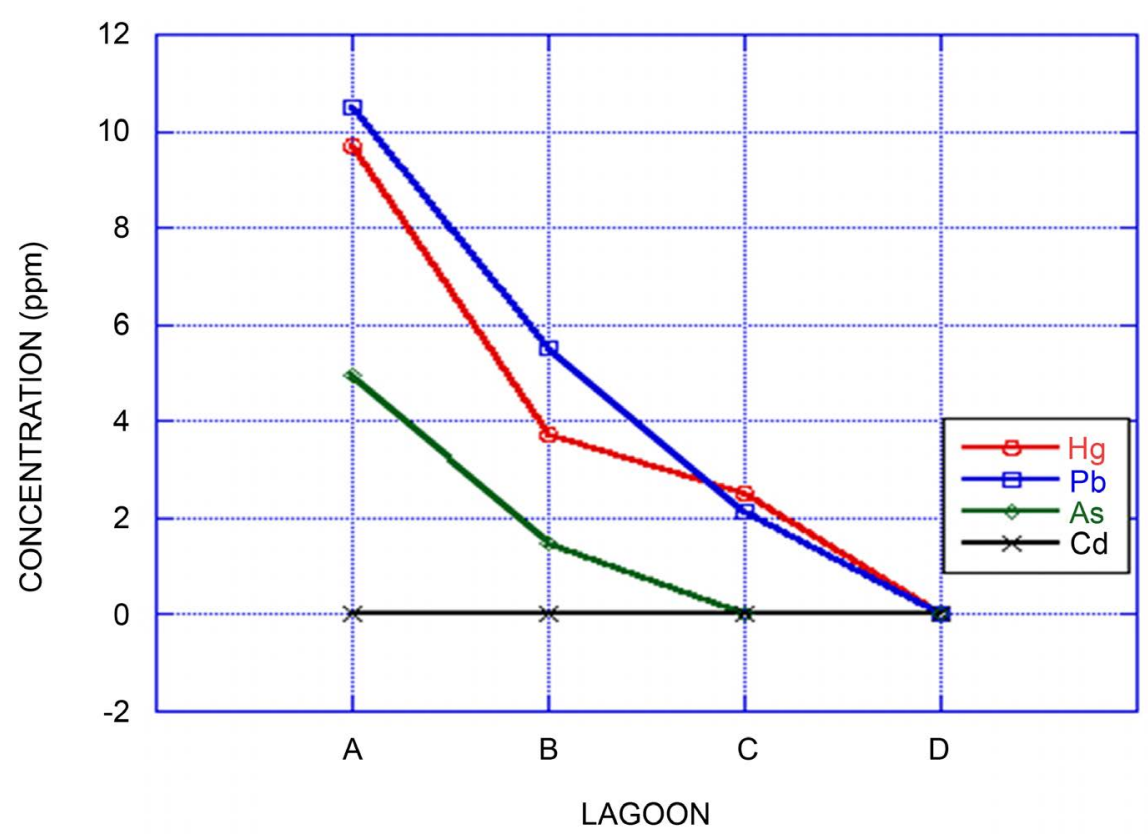

Figure 2. Variability of $\mathrm{Hg}, \mathrm{Pb}$ and $\mathrm{AS}$ across the lagoons.

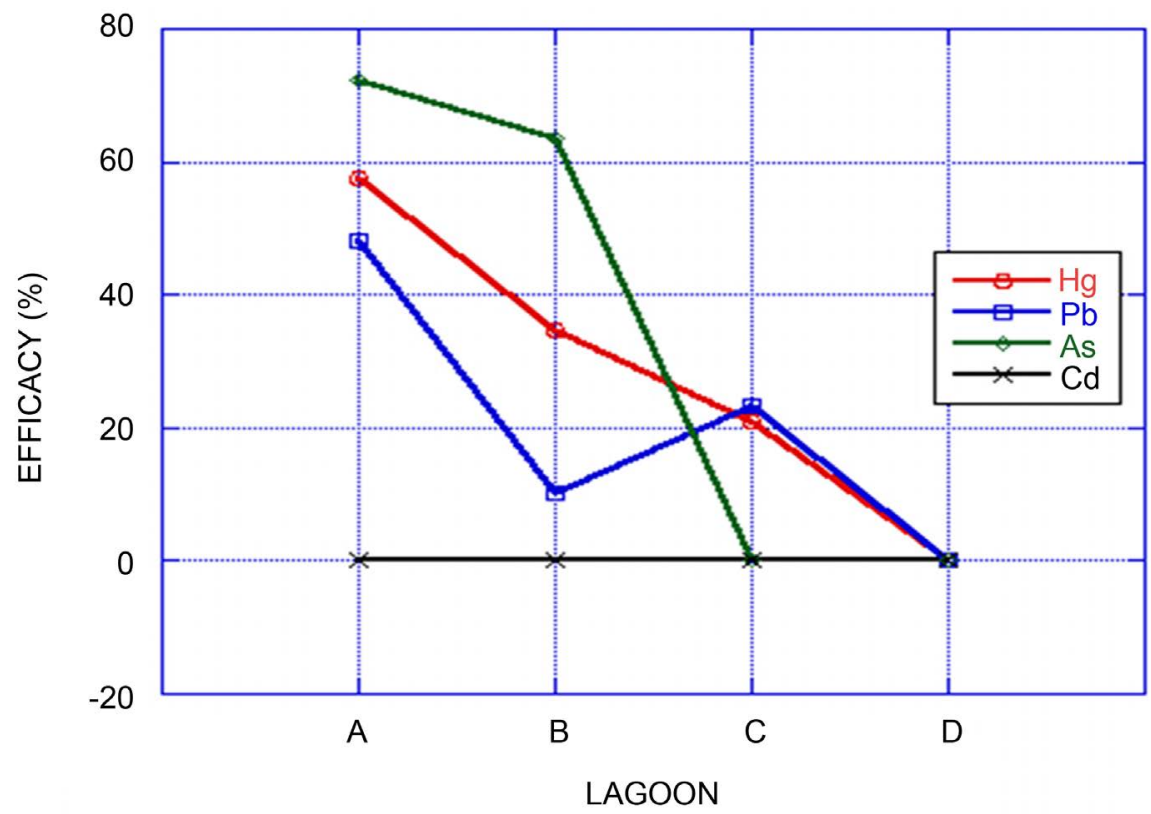

Figure 3. Efficacy assessment across the lagoons.

$\mathrm{B}$ and $\mathrm{C}$ respectively. An increase in the efficacy from $10.17 \%$ to $23.33 \%$ as the slurry enters lagoon $\mathrm{C}$ from $\mathrm{B}$ is a pointer to enhanced treatment of $\mathrm{Pb}$ in lagoon B. Arsenic on the other hand registered $72.25 \%$ and $63.55 \%$ efficacy in lagoon A and B. As was not detected in the third lagoon which may suggest that all of it was removed from the sludge after treatment in lagoon B. Basing on the non-detection of heavy elements in lagoon $\mathrm{D}$, its efficacy in the treatment was $100 \%$, an indicator of superb treatment of these heavy elements in this lagoon. The efficacy in the removal of heavy metals assessed in the study of heavy metal 
concentration and variation in sewage effluents realized $24.9 \%$ to $79.0 \%$ for $\mathrm{Hg}$, $54.2 \%$ to $78.9 \%$ for $\mathrm{Pb}, 6.8 \%$ to $31.7 \%$ for As and $0.4 \%$ to $87.3 \%$ for $\mathrm{Cd}$ [16]. The efficacies of heavy metal treatment in this work were within the range of [16] except for As which was higher in this work (63.55\% to $72.25 \%$ ), this can be attributed to the variations in the loadings.

\section{Conclusion}

This study was undertaken to perform elemental analysis of sewage effluents from Kibabii University sewage treatment system using EDXRF spectroscopy for analysis of the efficacy of the sewage treatment system. Mercury $(\mathrm{Hg})$ had a mean concentration of $9.705 \mathrm{ppm}, 3.745 \mathrm{ppm}, 2.535 \mathrm{ppm}$ and $0 \mathrm{ppm}$ in sediments from lagoons $\mathrm{A}, \mathrm{B}, \mathrm{C}$ and $\mathrm{D}$ respectively. Lead $(\mathrm{Pb})$ metal concentration level averaged at $10.50 \mathrm{ppm}, 5.51 \mathrm{ppm}$ and $2.12 \mathrm{ppm}$ respectively across the lagoons A, B, C and D. Arsenic (As) on the other hand had an average concentration of $4.95 \mathrm{ppm}$ and $1.46 \mathrm{ppm}$ in lagoons $\mathrm{A}$ and $\mathrm{B}$ respectively; whereas none in lagoons $\mathrm{C}$ and $\mathrm{D}$. There was no detection of $\mathrm{Hg}, \mathrm{Pb}$, and $\mathrm{As}$ in the liquid samples across the lagoons attributed to their low abundance in the liquid samples. The efficacy in the treatment of $\mathrm{Hg}$ was $57.47 \%, 34.66 \%$ and $20.85 \%$ in lagoons $\mathrm{A}, \mathrm{B}$ and $\mathrm{C}$ respectively. $\mathrm{Pb}$ treatment by the system realized an efficacy of $48.23 \%$, $10.17 \%$ and $23.33 \%$ in lagoons A, B and C respectively. Arsenic on the other hand was treated with an efficacy of $72.25 \%$ and $63.55 \%$ in lagoons A and B respectively. Based on the above findings, the study was successful in undertaking the elemental analysis in order to assess the efficacy in the treatment process by Kibabii University sewage treatment system. The users of water from River Kibabii therefore have less to worry as pertaining to water safety. However, a combined approach from the University and the surrounding community should be embraced in order to enhance the treatment process and constantly share the information on the heavy elemental concentrations so as to alleviate worries over the heavy metals concentrations released into the River after treatment.

\section{Acknowledgements}

The authors are pleased to acknowledge the University of Nairobi, Department of Physics, for availability and technical support in the utility of EDXRF spectrometer in sample analysis.

\section{Conflicts of Interest}

No conflict of interest at all.

\section{References}

[1] Borges, R.C., Filho, S. and Caldas, V.G. (2014) Use of GLS for Evaluation of Heavy Metal Contamination in the Cunha Canal Watershed and West of the Guanabra Bay, Rio de Janeiro. Marine Pollution Bulletin, 89, 75-78.

https://doi.org/10.1016/j.marpolbul.2014.10.033 
[2] Lazor, P., Tomas, J. and Cereyora, S. (2012) Monitoring of Air Pollution and Atmospheric Deposition of Heavy Metals By Analysis of Honey. Journal of Microbiology, Biotechnology and Food Sciences, 1, 522.

[3] Oluyemi, E.A. and Olabanji, I.O. (2011) Heavy Metals Determination in Some Spiecies of Frozen Fish Sold at the Ile-Ife Main Market, South West Nigeria. Ife Journal of Science, 13, 86-93.

[4] Stevens, M. (2017) Environmental Regulation for Sewage Treatment Plants. South Australian Government. http://www.epa.sa.gov.au

[5] Campos, C.J. (2014) Environmental Transmission of Human Noroviruses in Shellfish Water. Journal of Applied Environmental Microbiology, 80, 3552-3561. https://doi.org/10.1128/AEM.04188-13

[6] Visumzi, M. (2013) Impacts of Poorly Maintained Wastewater and Sewage Treatment Plants: Lessons from South Africa. Council of Scientific and Industrial Research, 1.

[7] Pure Earth Organization (2016) Tanzania Wastewater Treatment. http://www.purearth.org

[8] Wang, H.T., Wang, T. and Zhang, B.R. (2013) Water and Wastewater Treatment in Africa-Current Practices and Challenges. CLEAN-Soil, Air, Water, 42, 1029-1035. https://doi.org/10.1002/clen.201300208

[9] Rono, A.K. (2017) Evaluation of TSS, BOD5 and TP in Sewage Effluent Receiving Sambul River. Journal of Pollution Effects \& Control, 5, 189.

[10] Mbula, A. (2018) Kisii Town Health Concerns as Raw Sewage Flows into River Chania. http://www.standardmedia.com

[11] Ogoyi, D.O., Mwita, C.J., Nguu, E.K. and Shiundu, P.M. (2011) Determination of Heavy Metal Content in Water, Sediment and Microalgae from Lake Victoria, East Africa. The Open Environmental Engineering Journal, 4, 156-161. https://doi.org/10.2174/1874829501104010156

[12] Vohland, M., Bossung, C. and Frand, H.C. (2009) A Spectroscopic Approach to Assess Trace-Heavy Metal Contents in Contaminated Flood Plain Soils via Spectrally Active Soil Components. Journal of Plant Nutrition and Soil Science, 17, 201-209. https://doi.org/10.1002/jpln.200700087

[13] Rousseau, R.M. (2006) Corrections of Matrix Effects in X-Ray Fluorescence Analysis-A Tutorial. Spectrochimica-Acta Part B, 61, 759-777. https://doi.org/10.1016/j.sab.2006.06.014

[14] Jenkins, R. (1999) X-Ray Fluorescence Spectrometry. 2nd Edition, Wiley, New York, 6. https://doi.org/10.1002/9781118521014

[15] Von Canstein, H., Li, Y., Timmis, K.N., Decjwer, D. and Wagner-Dobler, I. (1999) Removal of Mercury from Chloralkali Electrlysis Wastewater by Mercury-Resistant Pseudomonas putidastrain. Journal of Environmental and Public Health Microbiology, 65, 5279-5284.

[16] Chanpiwat, P., Kyoung-Woong, K. and Su Thipong, S. (2008) Metal Contents and Its Variation in Wastewater and Wastewater Sludge: A Case Study of Bangkok Central Wastewater Treatment Plants. Proceedings of the International Symposia on Geoscience and Resources and Environments of Asian Terranes, Bangkok, 24-26 November 2008.

[17] Spanos, T., Ene, A. and Karadjova, B. (2014) Assessment of Toxic Elements Cu, Ni, $\mathrm{Pb}, \mathrm{Cd}, \mathrm{Hg}, \mathrm{Zn}$, and As in Sewage Sludge from Municipal Wastewater Treatment Plants by Combined Spectroscopic Techniques. Journal of Environmental Physics, 
60, 237-245.

[18] Perusini, H. (2016) Temporal Variation of Mercury in Effluent from Two Municipal Wastewater Treatment Plants in Southwest Ohio. Master of Science Thesis, CORE Scholar, Wright State University.

[19] Monika, D., Kawser, A., Shahidul, I. and Mosammat, S. (2011) Heavy Metals in Industrial Effluents (Tannery and Textile) and Adjacent Rivers of Dhaka City, Bangladesh. Terrestrial and Aquatic Environmental Toxicology, 5, 8-13.

[20] Ogunleye, I.O. and Izuagie, A. (2013) Determination of Heavy Metal Contents in Some Industrial Effluents from Ondo State, Nigeria. Journal of Environmental Chemistry and Ecotoxicology, 5, 216-219.

[21] Mekuyie, M.F. (2014) Heavy Metal Concentration in Effluents of Textile Industry, TikurWuha River and Milk of Cows Watering on This Water Source. Research Journal of Environmental Sciences, 8, 422-434. https://doi.org/10.3923/rjes.2014.422.434

[22] Najam, S., Nawar, R., Ehsan, M.M. amd Nawaz, M.H. (2015) Heavy Metal Contamination of Soils and Vegetables Irrigation with Municipal Wastewater: A Case Study of Faisalabad, Pakistan. Journal of Environmental and Agricultural Sciences, 4, 6-10.

[23] World Health Organisation (WHO) (2007) Health Risks of Heavy Metals from Long-Range Transboundary Air Pollution. Copenhagen.

[24] Oliveira, A., Munoz, S. and Bocio, A. (2007) Heavy Metals in Untreated/Treated Urban Effluent and Sludge from a Biological Wastewater Treatment Plant. Environmental Science and Pollution Research-International, 14, 483. 